\title{
OTRA VEZ SOBRE SINCRETISMO
}

\author{
MANUEL GUTIÉRREZ EsTÉVEZ ${ }^{1}$ \\ Universidad Complutense de Madrid
}

Resumen: Este texto es una nueva reflexión sobre el sentido del sincretismo entre pueblos indígenas de América. Frente a la opinión extendida de que estos pueblos son el ejemplo más claro de sincretismo, se defiende la idea de que las sociedades indígenas no han formado culturas sincréticas sino que las distintas tradiciones presentes en ellas (la cristiana y la "pagana») están claramente diferenciadas y cumplen funciones distintas.

Palabras clave: sincretismo, pueblos indígenas de América, hibridismo, heteroglosia.

AвSTRACT: This text is a new reflection on the meaning of syncretism among the indigenous peoples of America. In contrast to the widespread view that these peoples are the clearest example of syncretism, the idea defended here is that indigenous societies have not formed syncretic cultures but that, rather, the different traditions (Christian and "pagan») present are clearly differentiated and fulfill distinct functions.

KeYwORDs: syncretism, indigenous peoples of the Americas, hybridity, Amerindian, heteroglossia.

«Todos los males destos miserables indios son males en la vejez adquiridos en la mocedad; pues habiendo pasado ciento y treinta y seis años (ahora serían casi quinientos y veinte años) despues de la publicacion del santo Evangelio, se quedaron con aquellos resabios de su gentilidad» (Serna, 755).

Mi argumento en estas páginas ${ }^{2}$, de modo esquemático, es el siguiente: el concepto de sincretismo puede ser objetado, tanto por consideraciones morales sobre su tácito etnocentrismo, como por refutaciones lógicas sobre su incapaci-

1 gutieste@futurnet.es

2 Una primera versión fue presentada en la Universidad de La Sapienza, Roma, en mayo del 2003, durante un simposio organizado por Alessandro Lupo bajo el título de «Gli indigeni messicani oggi. Protagonisti e dinamiche dell'identità etnica». 
dad para discriminar religiones «sincréticas» $\mathrm{y}$ «puras». Pero, estos dos órdenes de impugnación al concepto han llegado a ser obvios y no voy a ocuparme de ellos. Dejando al margen la moral y la lógica, voy a centrarme solo en la etnografía. Si el rasgo más definitorio del fenómeno del sincretismo es la presencia de la mezcla de tradiciones heterogéneas, mi argumento etnográfico es que tal mezcla no existe en las culturas amerindias que, por haber sido objeto de una evangelización intensa, son las que, de preferencia, reciben el calificativo de «sincréticas». En mi opinión, las diferentes tradiciones que mantienen su vigencia en estas culturas están, como en el dicho castellano, «juntas pero no revueltas». Esto, de un modo muy simplificado, quiere decir que la tradición «cristiana» no está confundida con la tradición "pagana» sino que están diferenciadas y cumplen funciones diferentes de significación del mundo. Naturalmente, que ni la tradición «cristiana» ni la "pagana» son a-históricas y ambas se han ido transformando profundamente. Lo que implica que el cristianismo de numerosas sociedades amerindias es un cristianismo muy distinto del romano y marcadamente local, resultado de adaptaciones, re-interpretaciones y malentendidos de la tradición originaria. Y que lo mismo vale decir para la tradición "pagana» que, también, es, en la actualidad, muy diferente - por reducción del repertorio original, por adaptación a nuevas estrategias identitarias, por empobrecimiento ritual como efecto de la subordinación colonial y por otros factores - de la que pudo estar en vigor en tiempos pre-hispánicos (por eso es incorrecto nombrarla como tradición o religión "pre-hispánica» y prefiero denominarla con la vieja y noble expresión de «pagana»).

La co-presencia de estas dos tradiciones (que, sin duda, tienen entre sí interferencias resultado de su solapamiento de funciones en algunos áreas de la vida social, pero no en otras) fue muy bien vista por algunos de los evangelizadores de la época colonial. Nuestra corporación académica ha tendido a suponer que la situación fue transitoria y que el transcurso del tiempo produjo la mezcla, el sincretismo, y terminó con la dualidad. Mi opinión, por el contrario, es que la situación se ha mantenido hasta hoy y que la peculiar lógica del monoteísmo no ha penetrado en las conciencias amerindias, sino que éstas han seguido «recalcitrantes» con su lógica del paganismo que no ve inconveniente alguno en sumar creencias y prácticas de cualquier origen. Si esto es así, entonces, nuestras tareas de investigación son diferentes de las que pensábamos y pasa a tener prioridad el estudio de las formas de relación que tienen entre sí los elementos de las diversas tradiciones presentes en una cultura. Estudiar formas de relación quiere decir atender más a la sintaxis que a la semántica, más a la retórica que a la metafísica y más a los procesos de incorporación que a los resultados «barrocos», «creativos» y «sincréticos» o «híbridos». 
El concepto de "hibridismo", aunque con algunas diferencias significativas, no es sino la puesta al día del viejo término de sincretismo; podríamos decir que es su restauración ilustrada para una época de globalización. Ambos conceptos, aunque con diferencias entre ellos, son el resultado de una perspectiva metafísica (de indagación sobre el ser y la identidad) y monológica (de primacía del principio de no-contradicción). En mi opinión, deberíamos descartar estos conceptos integradores y, en su lugar, intentar entender una pauta cultural de agregación indiscriminada e incoherente que va conectando entre sí materiales desacordes mediante relaciones de analogía, metonímicas, de homofonía y otras posibles que han de ser exploradas. El esfuerzo que, en el pasado, se ha hecho para determinar si el «sincretismo» es creación de algo nuevo, o es desajuste, o es estrategia de resistencia, me parece un esfuerzo baldío, que ha dado malos resultados ${ }^{3} y$ que ha de ser sustituido por el esfuerzo para entender las diversas formas de conectividad entre los fragmentos heterogéneos y ajenos que los pueblos indígenas, en un proceso histórico continuo, incorporan a su «enciclopedia» cultural. Lo que nos ha de llevar a reconsiderar, no sólo las diferencias entre las lógicas escriturarias y las de la oralidad, sino también, y sobre todo, las diferencias entre las lógicas del monoteísmo y las del politeísmo (para lo cual, los conceptos bajtinianos de "polifonía» o de "heteroglosia» suponen alguna ayuda; aunque también, probablemente, nos serían de provecho otros conceptos como los de «fuzzy set» o lógica borrosa y otros procedentes de la semiótica de Peirce).

Para hacer las cosas conforme al estilo de nuestra corporación académica, podemos empezar por algo de etnografía mediante una breve referencia al modo en que los mayas yucatecos de Campeche, los mayeros, piensan sobre el Juicio Final $^{4}$.

3 Bernand, C. y Gruzinski, S. en su obra, tan sugerente, De la idolatría. Una arqueología de las ciencias religiosas, afirman (1992:152): «...sería deseable que dejaran de pensarse en términos de 'sincretismo religioso' estos fenómenos que rebasan ampliamente esa red y que se emprendiera la tarea de actualizar otras configuraciones que no solamente redistribuyan los rasgos de lo real observado, sino también puedan exhumar otros, ya se trate de darles una importancia que se les había negado o de sacarlos de la nada en que hasta entonces los había dejado la investigación».

${ }^{4}$ Una descripción más detallada puede verse en Gutiérrez EstÉvez, M., "Cosmovisión dualista de los mayas-yucatecos actuales», 2002: 365-387. 
La tradición cristiana mediterránea ha representado en numerosas ocasiones a San Miguel aplastando al dragón luciferino; los mayas yucatecos ven, ahora, esa figura monstruosa como X-Kukicán y como Kukulcán, la serpiente emplumada que deificaron sus antecesores y que ellos, en cambio, al hacerse cristianos, han satanizado, no sin dudas e imprecisiones. Pero el Juicio Final, al término de esta edad del mundo, constituirá una «prueba» que forzará la supresión de cualquier ambigüedad en el trato con los diversos rostros serpentinos del mal moral.

De una manera especialmente dramática, el dilema ¿jesús o Kukulcán? se le va a plantear a cada hombre, a cada maya yucateco presente en "la justicia» que, sin tardar mucho, se hará en las viejas ruinas de Uxmal. A los «milperos» del común, el Anticristo (X-Kukicán, la serpiente con alas) les arrancará las uñas mientras les interroga sobre su doble lealtad:

«A nosotros, inocentes, viene el Anticristo y te saca una uńa:

- ¿Quién es tu Dios?

- Nuestro Señor Jesucristo.

Te saca otra, otra, otra. Y no te niegas, sino que la primera palabra se lo estás corrigiendo. Después te quita las uñas de tus pies, preguntando:

- ¿Quién es tu Dios?

Y tú sigues diciendo que nuestro Señor Jesucristo es tu Dios. Te quita las veinte uñas y, si no te arrepientes a decir: 'tú eres mi Dios', entonces te empuja. Nuestro Señor Jesucristo, que está al lado de San Pedro, le dice a él:

- Pedro, compone ese cuerpo que le echaron a perder.

Entonces San Pedro recoge las uñas, te las va pegando. ¡Ya! Estás en la mano derecha de nuestro Señor. Ya estás castigado, estás salvo, eres gente de Dios. Hay veces que no sabemos nosotros lo que decimos; muchos insultos. Si yo estoy insultando cualquiera palabra, no tengo a Dios en cuenta; estoy invertido a lo malo, no puedo entrar a los cielos. Por eso es el castigo que va a llevar; esa es la falta que tiene que pagar con las uñas que nos quitan».

El Juicio Final de los «mayeros» no es propiamente un «juicio», sino una «prueba» con significado de rito "de paso» o iniciático. Las gentes comunes, según se dice en el texto anterior, son «inocentes»; no es preciso, pues, que sean «juzgadas». Su única culpa procede de una mala utilización de la palabra («si estoy insultando cualquiera palabra, no tengo a Dios en cuenta») y, en conse- 
cuencia, su salvación procede también de la palabra. Declarando cuál es su Dios, el maya yucateco "tiene a Dios en cuenta» y contrarresta así su «inversión a lo malo» manifestada mediante el insulto, la palabra descontrolada. Por la palabra se condena y por la palabra se salva. Mientras San Pedro niega, con su palabra, a Cristo por tres veces (S. Mateo, XXV, 69-75), el mayero lo ha de afirmar veinte veces; el número tres y el número veinte son los que corresponden a los fundamentos lógicos de la temporalidad en sus respectivas culturas, la trinitaria mediterránea y la vigesimal yucateca.

$\mathrm{Al}$ ser sometido a la prueba de perder, una tras otra, sus uñas, el mayero tiene que manifestar su capacidad heroica para controlar su expresión. En el escenario de la ciudad de Kukulcán (sea en Chichén Itzá, donde se representa en relieve a la Serpiente Emplumada, o sea en Uxmal, donde, otros, simbólicamente sitúan su sede), en la situación extrema del Juicio, el maya yucateco se ve obligado a pronunciarse respecto a unos términos que, en su vida cotidiana y secular, ha procurado no tener que plantearse como disyuntivos: Cristo y Kukulcán. En la vida cotidiana, los ha tratado en sus plegarias y rituales, incluso, como complementarios, implorando protección, simultánea o alternativamente, a San Miguel (como patrón de los chac'ob, de los regadores) y a Kukulcán (como señor de los vientos, merced a los cuales el h'men puede curar las enfermedades). Ahora, en cambio, en el Juicio Final, sólo uno de ellos puede ser reconocido como Dios y el otro, necesariamente ha de ser representado como su antagonista. ¿Cristo o Anticristo?, ¿Cristo o Kukulcán? esta es la pregunta cuya respuesta no puede demorarse más. El «juicio» es una prueba de lealtad y de ella sale el hombre convertido, de manera inequívoca y sin ambigüedad, en «gente de Dios» o «gente del Anticristo», de Kukulcán.

La proclamación verbal de la identidad moral con Cristo se hará, en el Juicio Final, durante el transcurso de un proceso de descomposición del ser. Arrancándole las uñas, se rompe su relación con el antiguo orden temporal. Durante la prueba del Juicio Final, el maya yucateco, será descompuesto progresivamente en sus veinte partes; será muerto metonímicamente veinte veces y, en cada una de sus muertes, va a negar a Kukulcán y a X-Kukicán, al garante postclásico de todo el sistema del tiempo y al albacea contemporáneo de la herencia maya. Después de haber muerto simbólicamente como uinic, renacerá como «gente de Dios»; la acción de San Pedro, emblema de la Iglesia, le constituirá con un ser unitario despojado ya de su dualidad, de su obligada doble lealtad a Cristo y Kukulcán. El pasado«maya», con el Juicio Final, será convertido en un pasado perdido y dejará de ser, como hasta ahora, un pasado antagónicamente vivo en la cosmovisión y en el sistema ético de los «mayeros» cristianos. 
Un sistema ético en el que «lo bueno» y «lo malo» se condensa y encarna en sendas figuras míticas que, como Cristo y Kukulcán, poseen una diferenciada y antagónica connotación étnica. La tensión ética adquiere, en estos casos, una dimensión étnica por la cual los «dioses» de otros pueden ser, a la vez o alternativamente, «dioses» o «demonios» propios. El sistema ético deja de ser, así, una fortaleza amurallada desde la cual se contempla y juzga a los otros grupos étnicos situados en su exterior, para ser, en cambio, el campo de la interacción y el conflicto con ellos. El otro, dentro de la conciencia moral, conserva sus rasgos étnicos distintivos y con ellos perfila su característica opción ética. La tensión ética, reforzada como conflicto étnico, no sólo atraviesa el sujeto moral, sino que también es utilizada para expresar la identidad personal y la identidad colectiva. No es sólo un caso particular de la dialéctica general entre el sí mismo y el otro como sí mismo (P. Ricoeur, 1990), sino que se trata de una situación en que el otro, siendo un otro étnico, además de objeto instalado en la conciencia, es, como Kukulcán, sujeto de las relaciones que conforman el orden moral del mundo, de las relaciones que, en su antagonismo con Cristo, edifican una específica teodicea.

Todos los actores de este drama, cósmico y cotidiano a la vez, son actores desconocidos históricamente, $y$ «heterogéneos» entre sí. Ni Cristo es el mismo que el conocido por los cristianos del Mediterráneo, ni Kukulcán es el que conocieron los antiguos mayas del postclásico. Pero permanecen, sin embargo, anclados imaginariamente en relación a sus respectivas tradiciones originarias. Cada uno de ellos, Cristo y Kukulcán, o X-Kukicán, conserva en su perfil simbólico la señal emblemática de un tiempo distinto (presente o pasado), de un espacio dispar (el del pueblo actual o el de las ruinas), de un grupo étnico diferente (el de los «mayeros» o el de los «mayas»). La redefinición de ambas figuras, lo que suele ser llamado su "sincretismo", no les ha hecho perder su condición de signos étnicos correspondientes a grupos que son pensados por los mayeros como antagónicos en el proceso de construcción de su identidad. La tensión disyuntiva entre ambas figuras, Cristo y Kukulcán ("¿quién es tu dios?»), muestra, de hecho, que no hay «sincretismo», que no hay mezcla o confusión de contrarios en el sistema ético, sino que éste es el escenario de una conflictividad étnica, diariamente evocada, que opone a los mayeros con los antiguos y desaparecidos «mayas». Se trata de una conflictividad, de una tensión, que sólo será disuelta en el final de este tiempo, el tiempo del cristianismo. Ya no será así después, cuando — conforme al conocido esquema temporal del joaquinismo- advenga el tiempo del Espíritu Santo. 
Pero, mientras llega esa nueva edad del mundo, cada mayero de nuestro tiempo no puede negar alguna clase de adhesión a las dos figuras antagónicas representativas de la sucesión de las diversas edades. Es una estrategia ética que se configura como resultado de las múltiples decisiones individuales que buscan disminuir los riesgos. Al estar sometidos los mayeros a dos poderes en conflicto, que implican lealtades excluyentes, cualquier cambio en la posición relativa de uno u otro de esos poderes tendría fatales consecuencias: o bien pierde efectividad el viejo poder de Kukulcán y de X-Kukicán (lo que significa aumento de las enfermedades o descontrol de las lluvias y, por tanto, pobreza), o bien disminuye la influencia de Jesús (lo que acarrea el incremento de la grosería y la falta de respeto, lo que se traduce en más conflictos interpersonales y en más hechicería). Estas alternativas no son hipotéticas; la actual proliferación de grupos religiosos en competencia, es interpretada por los «mayeros», no sólo como un signo más de la inminencia apocalíptica, sino también como una causa de la desorganización social creciente, de la falta de respeto propia de estos tiempos (porque a pesar de que, de hecho, «los hermanos» evangélicos sean moralmente más estrictos que los católicos han roto el consenso ritualista del pasado). Al abrir las compuertas del debate y la controversia religiosa, las iglesias protestantes han situado en el primer plano de la atención colectiva una cuestión que nadie quería plantearse hasta el día del Juicio Final: la cuestión del compromiso excluyente, de la adhesión íntima. Ya no puede seguir posponiéndose hasta el último encuentro en Uxmal la pregunta sobre la fe personal; ya no basta el acomodo colonial al doble poder de Cristo y Kukulcán. El desafío de estas alternativas éticas «evangélicas» es profundamente incómodo porque impide el mantenimiento de la doble lealtad de los «mayeros», esa doble lealtad tan sutil y trabajosamente elaborada durante siglos de sujeción y de malentendidos. Ahora, en el nuevo escenario del pluralismo religioso que se extiende por Yucatán, sólo los mayeros más conservadores siguen insistiendo en el valor del respeto, en la importancia de mantener a los mayas antiguos en su papel ambiguo de aliados y de adversarios, negándose a transformarlos en antepasados gloriosos como se hace en cualquier nacionalismo étnico de moda.

¿Sobre qué cuestiones nos hace pensar una descripción como la anterior u otras muchas semejantes que podrían traerse a colación? Según nuestras convenciones académicas, podría decirse que son ejemplos banales de sincretismo. 
A este modo de mezclar tradiciones de diverso origen y con distintos presupuestos conceptuales, a este modo de apropiarse y rehacer lo ajeno para fundirlo y confundirlo con lo propio, se le llama comúnmente así: «sincretismo». Es de sobra conocido que el término alude, por su etimología, a una coalición circunstancial de los cretenses frente a un enemigo común y, de forma figurada, a una conducta táctica de unión ficticia, engañosa y no selectiva entre elementos que de por sí son contrarios. Así fue utilizado por Erasmo en una carta a Melanchton para manifestarle el deseo de que los humanistas, pese a sus diferencias, se unieran entre sí frente a los rigoristas de la Reforma protestante y de la reacción católica.

Las connotaciones de táctica falaz y precaria que tiene el término se han mantenido en su aplicación a los pueblos amerindios que parecen ser sincréticos en tanto que, con disimulo, disfrazadamente, conservan creencias y prácticas paganas de tiempos antiguos. Adjetivándoles de «sincréticos» se les niega su condición de "auténticos» cristianos, lo que, en cambio e implícitamente, creen ser quienes utilizan el término. Lo sincrético es siempre cosa de los «otros»y «ellos» se harán acreedores a ese nombre de «sincréticos» cuando su actividad de apropiación indiscriminada de creencias, mitos o rituales ajenos se refiera, ante todo, a algo «nuestro», a algo del cristianismo romano en este caso. El término sólo puede aplicarse desde fuera, desde la exterioridad del propio grupo que ha realizado, a su conveniencia, una apropiación ilegítima de rasgos conceptuales o rituales para hacer con ellos una mezcla peculiar e imprevista, «vistiéndose estas vestiduras de color peregrino» (de la Serna, 750) ${ }^{5}$.

El término «sincretismo» se utiliza como el calificativo, más o menos especializado, que identifica las religiones de las culturas mestizas. Y así, se convierten en términos co-extensivos los de mestizaje y sincretismo. Como en el sincretismo, lo que caracteriza a lo mestizo es su mezcla y esta mezcla se manifiesta en un continuo tal que es difícil, si no imposible, aislar los elementos que entran en ella y su proporción en el conjunto general. De ahí, la prolijidad expansiva de la terminología descriptiva de los mestizajes — que se manifiesta, durante el siglo XVIII, en las pinturas de castas (empezando, como es bien sabido, por las de mulato o zambo hasta llegar a las denominadas «salto p’atrás» $\mathrm{O}$ «no te entien-

5 Bernand, Carmen (2001), señala que Gregorio García, al referirse a los animales cimarrones que se habían multiplicado extraordinariamente en el primer siglo posterior a la conquista, habla de «animales peregrinas, animales mestizas» (probablemente, en el sentido figurado del término "peregrino» como algo extraño, especial, raro o pocas veces visto). 
do»)- . En el continuum de las variaciones fenotípicas mestizas es imposible establecer líneas de demarcación que permitan taxonomías consistentes. De modo semejante, el sincretismo plantea a los usuarios del concepto el problema de la identificación: ¿son cristianos o son idólatras enmascarados? Metafóricamente: ¿son «no te entiendo» $\mathrm{O}$ «salto p’atrás»?

Preguntas análogas, más o menos sofisticadas o ingenuas, conducen a la suposición tácita de que si existen «mestizajes»o «sincretismos» es porque hay algo que es su contrario, lo "puro", lo no mezclado ${ }^{6}$. Normalmente, se piensa que el grupo calificado de «sincrético» no tiene conciencia de que algo ajeno ha sido apropiado en algún momento de su pasado histórico y convertido inmemorialmente en algo indistinguible de lo propio. Se supone que lo heterogéneo, casi siempre heterodoxo, de su pensamiento o sus rituales sólo puede ser apreciado o visto como tal desde fuera y por quienes están investidos de alguna clase de autoridad, sea política o intelectual, para pronunciarse respecto a la legitimidad de su utilización (legitimidad que excluye las actividades de bricolage). Se supone, también, que para el grupo generador de un «sincretismo» no hay diferencias relevantes entre lo que históricamente procede de su propia tradición cultural y lo que procede de otras varias y diversas, cuando ya está todo ello amalgamado y mezclado, confundido, en su propia enciclopedia cognoscitiva.

Lo característico, pues, del concepto de sincretismo es su atributo de «mezcla». Sin mezcla, no se podría hablar de sincretismo, se podría hablar de "conversión» (esto es, de una adhesión substancial al cristianismo) o de "contumacia», una permanencia en las creencias y prácticas anteriores, calificadas durante siglos como «idolátricas». Lo que ha desafiado e impacientado a la valoración moral de los cristianos es que surgiera algo que entendieron como «mezcla», sospechando, además, que ésta mezcla era sólo apariencia o falsedad, disimulación de la idolatría antigua. Pareciera que, descartadas una y otra (la conversión y la contumacia) sólo pudiera quedar, como posibilidad lógica, la de la mezcla o sincretismo. Sin embargo más ajustado a la etnografía, y más complejo, es sostener que son $\mathrm{A}$ y $\mathrm{B}$, no una mezcla de A y B. Esto es, que los indígenas mexicanos, andinos u otros son cristianos, absolutamente cristianos (aunque no sean iguales que los cristianos romanos) y que son, a la vez y también absolutamente, otra cosa distinta y, desde cierto punto de vista, incompatible: son mayas o chortís o aymaras (aunque también lo sean de forma muy distinta a como en el pasado fueron mayas o

${ }^{6}$ Sobre este y otros aspectos relevantes del concepto de sincretismo puede verse el excelente trabajo de Lupo (1966). 
chortís o aymaras). Esto significa que hay unos cristianos, los amerindios, que, como si fueran posmodernos, no entienden su cristianismo como una exigencia de lealtad excluyente. Pero, para los cristianos romanos no es posible la doble lealtad ${ }^{7}$. Y a los indios, por tanto, habrá que predicarles pacientemente la doctrina para «desengañar a estos miserables ilusos, dandoles a entender, y conocer la pureza de Nuestra Sancta Fe, que no admite mezcla de otros Dioses, ni mezcla de errores, y supersticiones contra sus catholicas verdades» (Serna, 778).

Para estos indios «ilusos» el cristianismo se presentaba como un conjunto de referencias míticas, rituales y morales que pueden incorporarse, junto con otras de muy distinto origen, a la enciclopedia local a la que se acude para construir los significados que precisa la vida social. Y la totalidad de esta vida social, al decir de Acosta, está impregnada de cultos idolátricos:

«No (se) me ocurren palabras bastantes para dar a entender cómo están los ánimos de estos desgraciados, más que imbuídos, transformados totalmente en el sentimiento idolátrico; que ni en paz ni en guerra, en el descanso ni en el trabajo, en la vida pública ni en la privada, nada son capaces de hacer sin que preceda antes el culto supersticioso a sus ídolos. No se regocijan en sus bodas ni lloran en sus entierros, ni dan o reciben banquete, ni salen de casa, ni comienzan el trabajo sin que acompañe el sacrificio gentil. Tan oprimidos los tiene el demonio con miserable esclavitud. Y con cuánto artificio ocultan sus idolatrías y las disimulan, cuando no se las dejan hacer en público, y con cuánta impudencia pierden el seso en ellas, cuando creen que no se lo impedirán, es cosa que más puedo admirarla que declararla con palabras.» (Acosta, Predicación del Evangelio en las Indias, 1577, cap. IX del libro V).

Quienes estaban más próximos a la cura de las almas indias, sabían bien que no se trataba tanto de mezcla o sincretismo, sino que había que hablar más propiamente de ańadidos cristianos, de una expansión del repertorio mítico-ritual de los amerindios. Recuérdese, en este sentido, el término nahuatl de nepantla y su posible derivado nepantlismo ${ }^{8}$ como algo bien distinto al sincretismo. Como es bien sabido, el uso del término procede de Fray Diego Durán (1967; I: 237):

7 Bernand, Carmen, en el trabajo antes citado: «La imposible lealtad o el conflicto entre la naturaleza y la filiación», explora sutilmente las percepciones sociales de la dudosa o ambigua lealtad de los mestizos.

8 M. León-Portilla (1974: 24-25) comenta esta misma cita de Durán y ve en ella el esbozo de una teoría de nepantlismo cultural, «quedarse en medio, ofuscado lo antiguo y no asimilado lo nuevo". 
«Reprendiendo yo a un indio de ciertas cosas (... ) y así riñéndole el mal que había hecho, me respondió: Padre, no te espantes pues todavía estamos nepantla. Y como entendiese lo que quería decir por aquel vocablo y metáfora que quiere decir, estar en medio, torné a insistir me dijese qué medio era aquel en que estaban. Me dijo que, como no están aún bien arraigados en la fe, que no me espantase la manera que aún estaban neutros, que ni bien acudían a la una ley ni a la otra, o por mejor decir que creían en Dios y que juntamente acudían a sus costumbres antiguas y ritos del demonio. $Y$ esto quiso decir aquél en su abominable excusa de que aún permanecían en medio y estaban neutros"

Las expresiones de Durán son muy útiles para nuestra reflexión actual. Lo que ofende a Durán es esa aparente neutralidad que permite a su interlocutor declarar que puede creer en Dios y, a la vez, acudir a las antiguas costumbres y ritos. ¿Pero se trata de neutralidad? ¿Es cierto que estaban o están neutros? ¿No habría sido más correcto aceptar, aunque desafíe nuestro sentido común, que se trata de «acudir juntamente» — como el mismo Durán dice- a dos repertorios distintos de creencias y de rituales? Aunque a él, pero no a los indios, los «ritos del demonio" y la fe cristiana le parezcan contradictorios e incompatibles.

Eso es lo que dice también Jacinto de la Serna («venerando juntamente»), cuando escribe en 1656 su Tratado de las supersticiones..., y en el que su capítulo tercero sobre «Disimulación de ceremonias y ritos idolátricos» empieza así:

«Para mejor dissimular su engaño, y ponçoña, la doran, mezclando sus ritos, y ceremonias idolatricas con cosas buenas, y sanctas, juntando la luz con las tinieblas á Christo con belial, reverenciado á Christo Señor Nuestro, y á su sanctissima Madre, y á los sanctos (a quienes algunos tienen por Dioses) venerando juntamente á sus idolos.»"

Pensemos un momento en esta última frase «reverenciando (...) a los sanctos (a quienes alguntos tienen por Dioses) venerando juntamente á sus idolos». Lo que Jacinto de la Serna señala es el efecto asombroso de la relación que los indios establecen entre dos sistemas que consideran igualmente politeístas: uno, el cristianismo, con un politeísmo vergonzante, que se niega a sí mismo con tal carácter

9 Tratado de las supersticiones, idolatrías, hechicerías y otras costumbres de las razas aborígenes de México, por Jacinto de la Serna, 1656; cap. 3 «Disimulación de ceremonias y ritos idolátricos». 
y se presenta como monoteísmo, pero sin serlo; el otro, incontestable y evidente. La relación entre ambos es una relación de agregación, pero no de mezcla. Esto es, a los antiguos ídolos se añaden los nuevos santos y figuras de poder para reverenciar juntamente a todos ellos. Como dice el mismo de la Serna al final del apartado que dedica a describir los conjuros contra nubes y tempestades: «mezclan las cosas divinas, y de nuestra sagrada Religion con los abusos y torpezas de sus idolatrias, teniendo por cierto, que uno y otro se puede usar, y uno y otro es necessario.» Pero esta componenda pragmática no es legítima para un verdadero cristiano y de la Serna nos dice: «Desdichado de aquel que quiere entrar por dos caminos, y por dos caminos andar, que es obrar uno, y conocer otro: así estos miserables indios en el estado, que hoy están, quieren parecer Christianos siendo idolatras, pareciendoles, que lo uno, y lo otro pueden estar junto.»

La negativa a tal arreglo procede, a mi parecer, de tres principales factores: en primer lugar, como resulta obvio, por las mismas ideas cristianas sobre la naturaleza de la verdad, el error o la mentira como mutuamente excluyentes (lo que no sólo tiene una dimensión moral, sino, sobre todo, una formulación filosófica y, en este sentido, característicamente occidental); en segundo lugar, por cuanto la declaración monoteísta del cristianismo es impugnada cuando el cristianismo es tratado por los indios como si fuera un nuevo politeísmo proveedor de nuevos dioses (y la cuestión no era solamente un problema de evangelización, porque esa disputa estuvo avivando los conflictos sangrientos en Europa durante el siglo XVI por las acusaciones de los reformados a los papistas como idólatras y políteistas); podría decirse que las prácticas ceremoniales indias anulaban la sutil coartada teológica de la distinción entre el culto de latría y el de dulía ${ }^{10}$. Y en tercer lugar, la agregación de los dioses cristianos al panteón amerindio cuestiona la sinceridad de la conversión como algo personal — tal como se estaba entendiendo desde finales del siglo XV—. ${ }^{11} \mathrm{La}$ fe (acompañada y atestiguada por las obras) era una cuestión personal (y no de conveniencia social) y, por tanto, si los indios decían tener fe habían de ser coherentes con esa declaración y, en caso contrario, mostraban su naturaleza falsa y mentirosa.

${ }^{10}$ Dice de la Serna: «(...) es formal y verdadera idolatria, opponiendose tan de veras á la veneracion, y culto diuino, que á Dios Nuestro Señor se debe, que quitandolo de su diuina, y soberana Magestad, lo ponen en los palos, en las piedras, y en falsos y fingidos Dioses.»

${ }_{11}$ El principio contrario cuius regio, eius religio (Paz de Augsburgo de 1555) no había sido sino una negociación con los principes alemanes que contradecía aspectos importantes (los mártires y la concepción paulina de conversión) de la propia historia del cristianismo. 
Nosotros, aunque no sintamos la ofensa moral o religiosa que sienten Durán o De la Serna, sí sentimos impugnada nuestra inteligencia lógica, y nuestras convenciones académicas, cuando escuchamos que pueden mantenerse, simultáneamente y de modo no provisional, creencias y prácticas contradictorias. Tampoco Acosta podía entenderlo, salvo que se «explicase» por su falsedad y mentira:

"Adoran a Cristo y dan culto a sus dioses; temen a Dios y no lo temen. (...) Le temen de palabra, mientras insta el juez o el sacerdote; le temen mostrando una apariencia fingida de cristiandad; pero no le temen en su corazón, no le adoran de verdad, ni creen con su entendimiento como es necesario para la justicia. Y para mayor abundamiento, sus hijos y sus nietos hacen lo que hicieron sus padres hasta el día presente. (Predicación del Evangelio en las Indias, cap. XIV, «Cómo es el cristianismo de los indios»)

En primer lugar, este creer y no creer ¿es un modo de nombrar al eclecticismo? ¿Se trata, no de una táctica de resistencia ante la evangelización, sino de una pauta cognitiva de larga duración? Si fuera así, ¿¿debemos extender a los indígenas mesoamericanos, y a otros intensamente cristianizados, las tesis de Viveiros de Castro (1993) sobre los tupinamba y otros pueblos amazónicos, en el sentido de que su identidad está hecha mediante la apropiación del afuera, de la exterioridad? Viveiros sugiere la no pertinencia de la categoría de creencia, algo que aliviaría las angustias de Acosta y que es de importancia para nuestro argumento:

" Je suggère simplement que cette religion ne se formulait pas dans les termes de la catégorie de la croyance, que cet ordre culturel ne se fondait pas dans l'exclusion uniciste des ordres extérieurs et que cette société ne pouvait être pensée hors de sa relation intrinsèque avec l'altérité. Ce que je dis est que la philosophie tupinamba affirmait une incomplétude ontologique essentielle: incomplétude du socius, et, en général, de la condition humaine. Il s'agissait d'un ordre au sein duquel l'intérieur et l'idéntité étaient hiérarchiquement englobés par l'extériorité et par la différence, oú le devenir et la relation prévalaient sur l'être et la substance. Pour ce type de cosmologie, les autres sont une solution avant d'être — comme le furent les envahisseurs européens - un problème.»

Pero también puede pensarse, con buenas razones, que no es necesaria una explicación tan específica — referida a una determinada clase de cosmología—, y que la lógica apropiadora que se manifiesta en lo que se ha llamado sincretismo es la común y habitual de los sistemas politeístas; una manifestación del «genio 
del paganismo» (M. Augé, 1982). Aunque, si así fuera, como me inclino a pensar, tendríamos que establecer las diferentes clases de relaciones conectivas entre los materiales heteróclitos que forman parte de la siempre abierta enciclopedia cultural de los indios de México. Pero, antes de intentar algo en este sentido, tendremos que examinar, siquiera sea someramente, algunas ideas sobre el sincretismo y, luego, sus vínculos conceptuales con el hibridismo, el término parejo que hoy está más en boga.

En los procesos de sincretización podemos distinguir tres movimientos, que no son necesariamente secuenciales y que pueden ser simultáneos:

- Agregación o recepción de elementos dispares, heterogéneos, de origen cultural foráneo.

- Transformación de esos elementos.

- Combinación indiferenciada de tales elementos en una nueva configuración cultural «mestiza», esto es «mezclada».

Estos tres movimientos han recibido muy diferente atención por los investigadores. Algo el primero (la agregación y sus condiciones), bastante el segundo (la transformación) y muy poca o nula atención el tercero (la supuesta mezcla resultante), que ha sido objeto más de valoración que de análisis.

Respecto a la agregación, merece la pena recordar el interesante concepto de "cultura de conquista», acuńado por Foster desde la perspectiva de la antigua teoría de la aculturación, para referirse al proceso de selección que las culturas dominantes y donantes (la española y la católica) operan en sí mismas de modo tácito e involuntario, «informal», o explícito y decidido, «formal». En palabras de Foster (1962:36):

«La cultura de conquista - o una cultura de contacto- puede considerarse mejor como la totalidad de influencias donadoras, cualquiera que sea su origen, que se ejercen sobre una cultura receptora, canal por el cual las normas, los valores y las actitudes del grupo más fuerte se transmiten al más débil. Una cultura de conquista es el resultado del procesos que tamizan a la cultura más dinámica que se expande, separando y descartando un alto porcentaje de todos los elementos, complejos y configuraciones que en ella se encuentran y determinando nuevos contextos y combinaciones para su 
exportación. Es el resultado de un proceso en que la nueva faz de la cultura donadora arranca de la infinita variedad de formas originales y se enriquece con los elementos que la propia situación de contacto produce.»

Y un poco más adelante:

«La formación de una cultura de conquista se caracteriza por un proceso de 'despojo' o 'reducción' mediante el cual se elimina un gran número de elementos de la cultura donadora y se simplifica la complejidad y variedad de muchas configuraciones.»

Uno de los aspectos interesantes de este concepto de "cultura de conquista» es que hace una caracterización de las culturas o subculturas donantes, las que inducen el «sincretismo» de las otras, y que, aparecen, desde esta perspectiva, como culturas esquemáticas, fragmentarias y parcialmente articuladas (rasgos simétricos a los de las culturas receptoras, sincréticas). De manera análoga podemos considerar, no sólo la cultura española en la situación de "conquista», sino también el cristianismo en situación de evangelización, de misión (baste ver, a este respecto, los cánones de los Concilios Limenses o las recomendaciones sobre lo que se debe o no se debe explicar a los indios acerca del dogma cristiano o, incluso, lo que se les debe permitir o no en cuanto al uso de los rituales sacramentales).

Con respecto al segundo de los movimientos, el de "transformación», se enfatiza con frecuencia la "creatividad» de las síntesis o recombinaciones realizadas por las culturas indias. Es, por ejemplo, la conclusión de Nancy Farris que describe el sincretismo en Yucatán como «el proceso creativo efectuado por los mayas para reconstruir, adaptar y fusionar su «realidad» a las nuevas circunstancias derivadas de la evangelización», y añade que «el nuevo sistema fue una síntesis creativa que aprovechó, para su estructura ideacional la tradición indígena y combinó en distinto grado paganismo y cristianismo para articular formas nuevas» (cit. en Vogt, 1992: 292). Pero muy rara vez se presta atención a uno de los procesos fundamentales que da lugar al llamado "sincretismo" y que es un proceso de incomprensión generado por malentendidos culturales (algo que es muy poco "creativo»). Estos malentendidos en la relación intercultural, aunque ahora no tengo el tiempo para ejemplificarlos etnográficamente con detalle, se refieren a:

- Incomprensión de las figuras de la retórica ajena (por ejemplo, tomando metáforas por metonimias y viceversa). Un caso bien conocido de esto 
sería el de los animales emblemáticos de los evangelistas tomados por nahuales (es decir, una metáfora tomada por metonimia).

- Incomprensión de conceptos y símbolos por su traducción inadecuada o su descontextualización (como se manifiesta en las creencias indígenas sobre "pérdida del alma-sombra» o en los relatos sobre la pasión de Jesús entendida como una huida permanente ante una persecución de los judíos).

- Incomprensión de la clase de emociones «occidentales» implicadas en creencias, mitos o rituales (como la falta del «dolor de contrición» por los pecados cometidos). Lo que ha llevado a acusar a los indios de «ritualistas» o de "formalistas»; esto es, de carentes de emociones intensas en su vida religiosa y proclives, por tanto, a cualquier deslealtad.

Por lo que se refiere al tercer movimiento o proceso de sincretización propiamente dicho, podemos citar la síntesis que hizo Evon Z. Vogt (1992-290-92) en un trabajo dedicado a indagar la peculiar historia cultural de las cruces y los bastones de mando en Mesoamérica. Vogt distingue cinco posiciones respecto al sincretismo que, en rigor, pueden reducirse a dos:

- El sincretismo es un proceso en el que partes iguales de las culturas india y española, se combinan, recombinan, mezclan, fusionan o hibridan (la imagen exacta varía según el investigador) tanto en forma como en significado.

- El sincretismo es un proceso en el que los elementos españoles están «encapsulados» en los modelos culturales indios preexistentes (y persistentes). Posición que el mismo Vogt había defendido en 1969 respecto a Zinacantán.

Estas dos posiciones, en definitiva, no señalan sino que las culturas indias son, según los primeros, culturas «sincréticas» o, en el segundo caso, que son culturas indias «auténticas» con elementos foráneos que están simplemente «encapsulados» en ellas, sin mezclar. La perspectiva mayoritaria de los investigadores enfatiza el carácter de mezcla o fusión de las culturas indias «sincréticas». Por el contrario, la perspectiva que utiliza la metáfora del «encapsulamiento», evita las referencias a mezclas y combinaciones para, en cambio, atribuir a los elementos foráneos una condición periférica en las culturas indias que resultarían así «recalcitrantes» como las denominaban los misioneros. Pero también puede pensarse en otra cosa distinta a las dos anteriores: que tanto los elementos cristianos como los «nativos» están separados (lo que no quiere decir «encapsulados»), aunque su separación y diferenciación no impide que tengan relación entre sí (de carácter 
semejante a la que tienen los diversos elementos que comparten un mismo «campo", en el sentido que el término tiene en Bourdieu). Por otro lado, y objetando también a Vogt, pienso que ambos repertorios de elementos, foráneos o nativos, «cristianos» o "paganos», son igualmente centrales y ninguno es periférico. De modo tal, que podría decirse que las culturas indias son duales antes que sincréticas o que recalcitrantes (aunque hablar de «dual» es una simplificación errónea, de genealogía misional, puesto que son múltiples los diversos repertorios acumulados históricamente al depósito disponible para entresacar de él los significados más convenientes en cada caso o situación).

A la precaria y discutible noción del sincretismo, ¿qué aporta el nuevo concepto de hibridación? De modo sintético puede decirse que aporta una nueva manera de ver el movimiento de «agregación» reemplazando los ya históricos conceptos de «colonización» (cultura de conquista) y «evangelización» (cristianismo de misión) por el remozado concepto de "globalización». Será la nueva cultura global la que, ahora, cumpla respecto a las culturas indias el papel de «donante» de nuevos elementos que agregar a su configuración tradicional. Por lo que respecta, al movimiento que he llamado de «transformación», el concepto de hibridación pone más énfasis en la mecanismos de imitación (simulacro), de incrustación (nuevo término para algo quizá no muy diferente de la «encapsulación») y de re-semantización (la manera en la que, ahora, nos referimos a lo que antes llamábamos re-interpretación). Respecto al tercer movimiento, el del resultado de la combinación indiferenciada, las nuevas culturas híbridas no resultan distintas de las antiguas culturas sincréticas y el proceso mismo de sincretismo no difiere sustancialmente del de hibridismo.

Veamos brevemente, a este respecto, algunas referencias del nuevo prólogo elaborado por García Canclini a la última edición de su importante y merecidamente famoso libro Culturas híbridas. Estrategias para entrar y salir de la modernidad (2001).

Comencemos por la definición más general. García Canclini afirma: «entiendo por hibridación procesos socioculturales en los que estructuras o prácticas discretas, que existían en forma separada, se combinan para generar nuevas estructuras, objetos y prácticas» (Ibid.: III).

Esta definición — que está tipográficamente destacada mediante cursivas-, no me parece que ańada nada nuevo a lo que tradicionalmente ha sido llamado «sincretismo». No es diferente — salvo porque no está especializada en lo «reli- 
gioso»— de la caracterización hecha por Marzal (1985: 176) en su ambicioso intento de describir y entender el sincretismo mediante la comparación de los procesos llevados a cabo por los quéchuas del Cuzco, los mayas de Chiapas y los afroamericanos de Salvador de Bahía. Marzal define el proceso sincrético como:

«...la formación, a partir de dos sistemas religiosos, de otro nuevo, cuyas creencias, ritos, formas de organización y normas éticas son producto de la interacción dialéctica de los dos sistemas en contacto. El resultado de esa interacción dialéctica en los diferentes niveles del nuevo sistema religioso será, ya la "persistencia» de determinados elementos con su misma forma y significado, ya su pérdida total, ya la «síntesis» de otros elementos con sus similares de la otra religión, ya, finalmente, la «reinterpretación» de otros elementos.»

La utilidad del concepto de hibridismo para, como dice García Canclini, «desplazar el objeto de estudio de la identidad a la heterogeneidad y la hibridación interculturales» (pag. VII) era una utilidad que ya tenía el concepto de sincretismo que ha inspirado, durante décadas, trabajos sobre relaciones interculturales del primer proceso de globalización, el de la conquista y colonización de América por las naciones ibéricas. El propio autor parece aceptarlo cuando afirma que «si queremos ir más allá de liberar al análisis cultural de sus tropismos fundamentalistas identitarios, deberemos situar a la hibridación en otra red de conceptos: por ejemplo, contradicción, mestizaje, sincretismo, transculturación y creolización.» (pag. VIII) Conceptos, diría yo, que han sido familiares para todos y a los cuales el nuevo de hibridación si apenas añade algún matiz relativo a su intensidad. Dice así García Canclini: «Sin duda, corresponde hablar de sincretismo para referirse a la combinación de prácticas religiosas tradicionales. La intensificación de las migraciones, así como la difusión transcontinental de creencias y rituales en el siglo pasado acentuaron estas hibridaciones y, a veces, aumentaron la tolerancia hacia ellas, al punto de que en países como Brasil, Cuba, Haití y Estados Unidos se volvió frecuente la doble o triple pertenencia religiosa; por ejemplo, ser católico y participar en un culto afroamericano o en una ceremonia new age. Si consideramos el sincretismo, en sentido más amplio, como la adhesión simultánea a varios sistemas de creencias, no sólo religiosas, el fenómeno se expande notoriamente, sobre todo entre las multitudes que recurren para aliviar ciertas enfermedades a medicinas indígenas u orientales, y para otras a la medicina alopática, o a rituales católicos o pentecostales.» 
Es decir, que si entiendo bien, se afirma que el término "sincretismo» vale para las combinaciones tradicionales, pero para las modernas, o posmodernas, como son más intensas y se dan en un contexto moral de tolerancia, debe usarse el nuevo concepto de "hibridismo» ${ }^{12}$. Lo que quiere decir que «hibridismo» es el nombre de «nuestros» sincretismos; los de «ellos» pueden seguir siendo estudiados con la conceptualización convencional y tradicional. Dice Canclini: «Considero atractivo tratar la hibridación como un término de traducción entre mestizaje, sincretismo, fusión y los otros vocablos empleados para designar mezclas particulares» (pag. XXI). La expresión "un término de traducción», ¿quiere decir un término de convergencia y compromiso? ¿o quiere decir la traducción del viejo término de estirpe griega al nuevo término, un tanto genetista, propio de nuestro mundo global?

Pero la cuestión más difícil para nosotros, estudiosos de las culturas amerindias, no está resuelta. No nos basta con decir que los elementos incorporados son "contradictorios», porque, precisamente, lo que muestran estas culturas es que lo contradictorio no se corresponde con lo incompatible. Eso es lo que, a mi parecer, hay que explicar: la doble o la triple lealtad (que toma la apariencia de deslealtad o de indiferencia ecléctica) y la presencia contigua en una misma configuración cultural de elementos que siendo contradictorios desde el punto de vista de nuestra lógica, son tratados por los propios actores sociales como no disyuntivos, como alternamente preferenciales según el contexto o como meramente acumulativos.

El mismo Canclini, al citar los comentarios de Cornejo Polar, sitúa los problemas en un terreno que no es el de la fusión. Cornejo dice algo que para noso-

${ }_{12} \mathrm{Al}$ leer el borrador de este texto, García Canclini me hizo algunas observaciones que considero muy pertinentes y que ponen de manifiesto que no es correcto hablar de «hibridismo» como hago, sino de "hibridación»; éstas fueron sus palabras: «Comparto la preocupación por entender procesos de no integración de lo heteróclito, que por tanto pueden ser mal comprendidos bajo esquemas de sincretismo o hibridación. Acepto que muchos ejemplos indios y modernos no se dejan atrapar bajo esas nociones. Pero al mismo tiempo no puedo prescindir del concepto de hibridación a fin de nombrar múltiples procesos de mezcla, fusión, en los que desembocan los paralelismos, las relaciones de analogía, metaforización y metonimia intercultural. La música contemporánea (popular y las otras), la vida cotidiana de los migrantes, las artesanías y fiestas que estudié en México me siguen pidiendo hablar de hibridación. No de hibridismo, como dices, y recuerdo haber defendido más de una vez el carácter procesual de la hibridación como noción descriptiva de movimientos que pueden ir en varias direcciones, ser modulados de maneras diversas por distintos creadores y receptores, y casi nunca se quedan quietos como para admitir la contundencia del ismo». 
tros es etnográficamente obvio: que el migrante no siempre «está especialmente dispuesto a sintetizar las distintas estancias de su itinerario, aunque - como es claro- le sea imposible mantenerlas encapsuladas y sin comunicación entre sí». Cornejo advierte, según el resumen hecho por Canclini, como la oscilación entre la identidad de origen y la de destino a veces lleva al migrante a hablar «con espontaneidad desde varios lugares», sin mezclarlos, como provinciano y como limeño, como hablante de quéchua y de español. En ocasiones, decía Cornejo, se pasan metonímica o metafóricamente elementos de un discurso a otro. En otros casos, el sujeto acepta descentrarse de su historia y desempeña varios papeles «incompatibles y contradictorios de un modo no dialéctico»: «el allá y el aquí, que son también el ayer y el hoy, refuerzan su aptitud enunciativa y pueden tramar narrativas bifrontes y - hasta si se quiere, exagerando las cosas- esquizofréni-

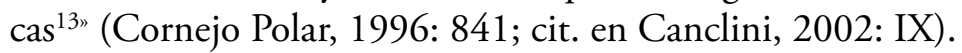

Estas consideraciones nos conducen a un concepto de hibridismo que no tiene nada de fusión y, por tanto, tampoco relación con el concepto de sincretismo. Nos conduce a una versión diferente de hibridación: la de Bajtin. Según la exposición de Rita de Grandis (1996), el discurso novelístico para Bajtín es un lugar híbrido, donde muchas voces desestabilizan la lengua unitaria y autoritativa o autorial. La novela (y, creo yo que se podría decir lo mismo de la culturas indígena) se constituye como un espacio conflictivo de interacción de dos o más voces, o conciencias. La condición o el locus dentro del cual el dialogismo en tanto proceso ocurre es denominado heteroglosia, o lugar de voces en oposición. La noción de dialogismo da cuenta de la existencia de una zona fronteriza entre espacios socio-culturales y socio-lingüísticos diversos, y cuyas delimitaciones y modalidades específicas de articulación histórica y literaria constituyen precisamente el objeto central del principio «dialógico bajtiniano.» Por otro lado, la noción de frontera, asociada por Bajtín con la de diálogo, hace que el crítico (o el etnólogo) deba ubicarse respecto de los espacios, los tiempos y los movimientos involucrados en las diferencias inherentes a la heterogeneidad cultural, el plurilingüismo o la heteroglosia. Rita de Grandis concluye afirmando que «es justamente en el plano de la articulación interna de la hibridación cultural dónde el modelo de Canclini debe desarrollarse, completarse con un instrumental más pormenorizado de análisis y es ahí donde el modelo de Bajtín puede ayudar».

13 Aunque no es exagerado usar el término de esquizofrenia. Hace bastantes años, lo utilizó Francesco Pelizzi (1982) para referirse a la identidad cultural en Chiapas. 
La ayuda que el modelo bajtiniano pueda prestarnos pasa, en mi opinión, y con esto ya termino, por discutir dos cuestiones: tomar la perspectiva, no del creador, sino la del receptor - lo que, en nuestro caso, significa la de los usuarios de una determinada cultura- $y$, en segundo lugar, discutir la analogía entre cultura y texto que justifica tácitamente el uso de las categorías bajtinianas.

Tomar la perspectiva del receptor significa disponerse a evitar preguntas acerca de la identidad, bajo cualquiera de sus formulaciones (incluyendo las que se refieren a identidades plurales y a identidades negociadas). Preguntar(se) por la identidad es adoptar modos de pensar característicos de nuestra cultura que ha creado una disciplina, la metafísica, para indagar sobre el ser. Pero tomar la perspectiva del receptor, también significa evitar la categoría de contradicción, por cuanto ésta sólo tiene sentido a partir de la primacía del principio lógico de identidad y no contradicción. En definitiva, adoptar la perspectiva del receptor, implica tomar la mayor distancia posible respecto al monoteísmo, no sólo en su específica formulación religiosa, sino en sus conexiones epistemológicas.

Y discutir los límites de la analogía entre texto y cultura resulta obligado al considerar el grado mayor o menor de la articulación interna entre los elementos de una determinada «enciclopedia» cultural. Porque un texto, una novela por ejemplo, incluso mirada a lo Bajtin, tiene un "programa narrativo», su polifonía no la anula como obra, esto es como unidad articulada. Pero, nuestro modo de recapacitar sobre la etnografía amerindia nos lleva, más allá de la polifonía, a sospechar la presencia de un grado importante de inarticulación. Diríamos, que nos conduce ante diversos "programas narrativos» superpuestos. Como si se tratara de un hiper-texto formado por agregación de párrafos procedentes de textos previos. Algo parecido, también, a un "cadavre exquis», a un cadáver exquisito de los que generaban lúdicamente los surrealistas. Ante esta clase de obras, ante esta clase de culturas (y todas lo son en mayor o menor medida), la crítica literaria bajtiniana también se queda corta. ${ }^{14}$

\section{Bibliografía}

Acosta, J. (1954) [1577]. «Predicación del Evangelio en las Indias» en Obras del Padre José de Acosta. Madrid: Atlas, pp. 388-608.

14 Véase a este respecto las sugerencias de Luciani (2001) sobre el concepto de personalidad fractal como una aproximación para entender el concepto amerindio de persona. 
AugÉ, M. (1982). Génie du paganisme. París: Gallimard.

Bernand, C. (2001). «La imposible lealtad o el conflicto entre la naturaleza y la filiación» en M. Dascal, M. Gutiérrez y J. de Salas (eds.), La pluralidad y sus atributos. Usos y maneras en la construcción de la persona. Madrid: Biblioteca Nueva, pp. 191-209.

Bernand, C. y Gruzinski S. (1992). De la idolatría. Una arqueología de las ciencias religiosas. México: Fondo de Cultura Económica.

Bourdieu, P. (1971). "Genèse et structure du champ religieux», Revue française de Sociologie, XII, pp. 295-334.

Cornejo, A. (1996). «Una heterogeneidad no dialéctica: sujeto y discurso migrantes en el Perú moderno», Revista Iberoamericana, Vol. LXII, n. ${ }^{\circ}$ 176-177.

Durán, D. (1967). [1570] Historia de las Indias de Nueva España e Islas de la Tierra Firme. México: Editorial Porrúa.

Foster, G. (1962). Cultura y Conquista. La herencia española en América. México: Universidad Veracruzana.

García Canlini, N. (2001). Culturas hibridas. Estrategias para entrar y salir de la modernidad. México: Grijalbo.

Grandis, R. (1996). «Incursiones en torno a hibridación. Una propuesta para discusión. De la mediación lingüística de Bajtín a la mediación simbólica de García Canclini,» Revista de critica literaria latinoamericana, n. ${ }^{\circ} 46$, pp. 37-52.

Gutiérrez Estévez, M. (2002). «Cosmovisión dualista de los mayas-yucatecos actuales», Religión Maya, Enciclopedia Iberoamericana de Religiones. Madrid: Editorial Trotta, pp. 365-387.

LeÓn-Portilla, M. (1974). «Testimonios nahuas sobre la conquista espiritual», Estudios de cultura nábuatl, vol. XI.

LuCiani, J. (2001). "Fractalidade e troca de perspectivas», Mana, vol.7, n. ${ }^{\text {2 }}$, pp. $95-132$.

Lupo, A. (1996). «Síntesis controvertidas. Consideraciones en torno a los límites del concepto de sincretismo", Revista de Antropología Social, n. ${ }^{\circ}$ 5, pp. 11-37.

Marzal, M. (1985). El sincretismo iberoamericano. Lima: Pontificia Universidad Católica.

Pelizzi, F. (1982). «Misioneros y Cargos: Notas sobre Identidad y Aculturación en los Altos de Chiapas», América Indígena, Año XLII, n.o 1, pp. 7-33.

Ricoeur, P. (1990). Soi-méme comme un autre. París: Editions du Seuil.

Serna, J. (1953). [1656] Tratado de las idolatrias, supersticiones, dioses, ritos, hechicerias y otras costumbres gentilicas de las razas aborígenes de México. Edición de Francisco del Paso y Troncoso. México: Fuente Cultural de la Librería Navarro, Tomo I, pp. 39-368. 
Viveiros de Castro, E. (1993). "Le marbre et le myrte. De l'inconstance de l'âme sauvage», en Mémoire de la Tradition, A. BecQuelin y A. Molinie (eds.) Nanterre: Société d'ethnologie, pp. 365-431.

Vogt, E. (1992). «Cruces indias y bastones de mando en Mesoamérica» en M. Gutiérrez Estévez et al. (eds.), De Palabra y Obra en el Nuevo Mundo. Vol. II, La formación del otro. Madrid: Siglo XXI, pp. 249-294.

Recibido: 20/02/2013

Aceptado: 5/05/2013 
